\title{
Assembling of Marketing Mix Model in Management Strategy of Tourism Destination in Lasiana Beach Kupang City East Nusa Tenggara
}

\author{
Veronika A.S.M Flora ${ }^{12}$, Sari Bandaso Tandilino ${ }^{2}$, Yudha E.Nugraha ${ }^{2}$ \\ \{veronikaflora1986@gmail.com, saribandaso@yahoo.com.yudhaekanugraha@gmail.com\} \\ Hospitality Study Program, Department of Tourism, Kupang State Polytechnic ${ }^{1}$ \\ Tourism Business Study Program, Tourism Department, Kupang State Polytechnic ${ }^{2}$
}

\begin{abstract}
The purpose of this research is to know the effect of marketing mix simultaneously and partially toward for tourist decision and to find out the alternative models of marketing strategy. The method of this research is mixed method with sequential explanatory. The result of the research shows that the marketing mix are influenced simultaneously and partially with seven variables: product, price, promotion, location, physical evidence, people and process toward tourist decision. The alternative model strategies that will be implemented are: SO is man made, WO is strength promotion program, ST is tariff standard of tourism object, WT is Providing extra services for tourists
\end{abstract}

Keywords. Tourism, Marketing Mix, SWOT

\section{Introduction}

Lasiana Beach has become an "image" of beach tourism destinations in Kupang City. Opened for tourists to visit since the $1980 \mathrm{~s}$ ( \pm 40 years, 2019). This beach is $\pm 12 \mathrm{~km}$ east of the city of Kupang, the entrance to the beach area is not far from the main highway, and can be passed by two-wheeled vehicles and four-wheeled vehicles.

The management of the Lasiana coast has moved from the Kupang City Government to the NTT Provincial Government since May 2019. This adds to the responsibility of the NTT Provincial Government which is currently making tourism a leading sector that is expected to be able to provide economic value to the community. The aim of tourism management is to balance economic growth and income with services to tourists and protection of the environment and preservation of cultural diversity, therefore the involvement of all stakeholders in the tourism sector is needed to integrate tourism management frameworks.

An understanding of the complexity of the nature of tourism product services is an essential prerequisite for achieving successful marketing devotion and the application of tourism marketing concepts is needed [1]. Whereas marketing mix is a combination of variables or activities that are the core of the marketing system, which variables can be controlled by marketers to influence consumers [2]. The traditional marketing mix concept previously consisted of 4Ps, namely: product, price, place / location and promotion that focused on real products only, whereas for service marketing it was necessary to expand the 
marketing mix with the addition of non-traditional marketing mix elements, namely: people , physical evidence and process so that it becomes seven elements or abbreviated as 7p [3].

At the time of observation, the writing of the gate sign entering the Lasiana beach area was not clearly read, the rubbish was still scattered close to the community housing around the coastal area. While in the Lasiana Coast area itself there are a number of "lopo-lopo", temporary play facilities for children are being improved. Facilities such as adequate and clean toilets. While there is still rubbish in the form of plastic bottles and food packaging still scattered, some of the bins provided have been damaged.

From interviews with the Chairperson of the Lasiana Coastal Area Manager, it is known that the level of tourist visits fluctuates tends to be quiet especially on weekdays. For holidays, it can be more than 50 vehicles, while for normal days it can be less than 50 vehicles owned by tourists. Although the entry ticket price per person has been abolished since May 2019, the

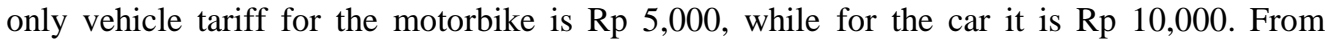
interviews with traders selling in the Lasiana beach area, they complained about the rental costs of the stalls set by the Provincial Government of East Nusa Tenggara, which were categorized expensive at Rp 100,000 per month, while their incomes tended to decline because a day of tourists who came shopping only around 5 people did not even shop altogether in their shanties, they continued the tendency of tourists who tend to prefer taking pictures in the beach area.

Based on the background description the researcher raised the title "Tourism Destination Management Strategies Through the Marketing Mix Model at Lasiana Beach, Kupang City, East Nusa Tenggara"

\subsection{Formulation Of The Problem}

1. Is there a marketing mix that consists of product, price, location promotion, physical evidence, people, processes, simultaneously on the decision of tourists to visit Lasiana Beach?

2. Is there a marketing mix which consists of product, price, location promotion, physical evidence, people, process, partially on the decision of tourists to visit Lasiana Beach?

3. What is the marketing mix strategy model that can be applied at Lasiana Beach?

\subsection{Research Purposes}

1. To determine the effect of the marketing mix consisting of products, prices, promotions, locations, physical evidence, people and processes simultaneously on the decision of tourists visiting Lasiana Beach.

2. To determine the effect of the marketing mix consisting of products, prices, promotions, locations, physical evidence, people and processes partially on the decision of tourists visiting Lasiana Beach

3. To find out the marketing mix strategy model that can be applied at Lasiana Beach?

\subsection{Research Benefits}

1. The results of this study can contribute to the thought of the East Nusa Tenggara Provincial Government related to the marketing mix aspect.

2. The results of the study can be used as contributions of ideas for other researchers who focus on the development of beach tourism destinations from the marketing mix aspect 


\section{Literature Reviews}

\subsection{Tourism, Tourist, Tourism Destinations, Marketing Mix and SWOT}

The definition of tourism according to the Law of the Republic of Indonesia No.10 of 2009 is a variety of tourism activities and is supported by various facilities and services provided by the community, business people, government, and regional government (Chapter I, Article 1, Paragraph 3)[5]. While tourists according to the Law of the Republic of Indonesia No.10 of 2009 article (1) states that tourists are people who carry out tourism activities. Law of the Republic of Indonesia Number 10 of 2009 Article (6) defines tourism destiny as a geographical area within one or more administrative regions in which there are tourist attractions, public facilities, tourism facilities, accessibility, and communities which are interrelated and complementary the realization of tourism.

Marketing is an organizational function and a set of processes for creating, communicating and delivering value to customers and managing customer relationships in ways that benefit the organization and its shareholders. When dealing with the exchange process there must be a large amount of work and skills[6]. Kotler continued in Hurriyati (2010: 47) stating that the marketing mix is a set of marketing tools that a company can use to achieve its marketing objectives in the target market. Zeithaml and Bitner in Hurriyati (2010) state that the concept of traditional marketing mix consists of 4P, namely: product, price, place / location and promotion. Meanwhile, for marketing services, it needs an expanded marketing mix with the addition of non-traditional marketing mix elements, namely : people, physical evidence and process, so it becomes seven elements or abbreviated as $7 \mathrm{p}$.

SWOT is an abbreviation of strength (strength), weaknesses (weaknesses) opportunities (opportunities) and threats (threats). SWOT analysis compares external factors which include opportunities and threats with internal factors which include strengths and weaknesses. In the stages of maturity and decline, companies are usually more oriented to the internal environment. The company is more focused on how to defend itself from a saturated market, a decline in sales figures, excess capacity, intense competition, and changing consumer tastes. The company began to decide whether to remain a market leader with superior production efficiency or look for market niches. At the lowest stage, the company will decide whether to streamline business, merge, or let go of business as soon as possible. The formulation of the strategy at this stage is more directed at the internal environment so that the SWOT matrix is used.

Table 1 Variables, Operational Definition Variables, Indicators and Measurement Scale

\begin{tabular}{|c|c|c|c|c|}
\hline No & Variabel & $\begin{array}{c}\text { Defenisi } \\
\text { Operasional } \\
\text { Variabel }\end{array}$ & Indikator & $\begin{array}{c}\text { Klasifikasi } \\
\text { (Skala Likert ) }\end{array}$ \\
\hline 1. & $\begin{array}{l}\text { Products (x1) } \\
\text { Tourism products } \\
\text { are tangible } \\
\text { products, these } \\
\text { products are a series } \\
\text { of services that not } \\
\text { only have economic } \\
\text { aspects, but also } \\
\text { those that are social, } \\
\text { psychological and }\end{array}$ & $\begin{array}{l}\text { Natural } \\
\text { attraction } \\
\text { Culinary tour } \\
\text { Artificial } \\
\text { tourist } \\
\text { attractions }\end{array}$ & $\begin{array}{l}\text { 1) Beautiful beach } \\
\text { panorama } \\
\text { 2) Beach Sand and Lontar } \\
\text { Plants typical of Kupang } \\
\text { City } \\
\text { 3) Kupang's special local } \\
\text { food menu } \\
\text { 4) Stage Facilities } \\
\text { 5) Children's play facilities }\end{array}$ & $\begin{array}{l}5=\text { Very interesting } \\
4=\text { Interesting } \\
3=\text { Interesting enough } \\
2=\text { Not interesting } \\
1=\text { Very unattractive }\end{array}$ \\
\hline
\end{tabular}




\begin{tabular}{|c|c|c|c|c|}
\hline & $\begin{array}{l}\text { natural, even though } \\
\text { the tourism product } \\
\text { itself is largely } \\
\text { influenced by } \\
\text { economic behavior } \\
\text { [7] }\end{array}$ & & & \\
\hline 2. & $\begin{array}{l}\text { Price (x2) } \\
\text { Price is the amount } \\
\text { of money needed to } \\
\text { exchange various } \\
\text { combinations of } \\
\text { products and } \\
\text { services [8] }\end{array}$ & $\begin{array}{l}\text { Some money } \\
\text { must be paid } \\
\text { by tourists } \\
\text { visiting the } \\
\text { Lasiana Coast } \\
\text { area }\end{array}$ & $\begin{array}{l}\text { 6) Entrance fee } \\
\text { 7) The price of snacks } \\
\text { provided at the location } \\
\text { 8) Costs for using the } \\
\text { facilities used } \\
\text { 9) Costs to compete with } \\
\text { other beach resorts }\end{array}$ & $\begin{array}{l}5=\text { Strongly Agree } \\
4=\text { Agree } \\
3=\text { Quite Agree } \\
2=\text { Disagree } \\
1=\text { Strongly Disagree }\end{array}$ \\
\hline 3 & $\begin{array}{l}\text { Promotion (X3) } \\
\text { Promotion is an } \\
\text { activity aimed at } \\
\text { influencing } \\
\text { consumers so they } \\
\text { can become familiar } \\
\text { with the products } \\
\text { offered by the } \\
\text { company and then } \\
\text { they become happy } \\
\text { and then buy the } \\
\text { product [9] }\end{array}$ & $\begin{array}{l}\text { Promotional } \\
\text { media used }\end{array}$ & $\begin{array}{l}\text { 10) From mouth to mouth } \\
\text { 11) 3rd party services } \\
\text { 12) Banners on Location }\end{array}$ & $\begin{array}{l}5=\text { Strongly Agree } \\
4=\text { Agree } \\
3=\text { Quite Agree } \\
2=\text { Disagree } \\
1=\text { Strongly Disagree }\end{array}$ \\
\hline 4 & $\begin{array}{l}\text { Location (X4) } \\
\text { Distribution or } \\
\text { location includes } \\
\text { company activities } \\
\text { so that products or } \\
\text { services are easily } \\
\text { available to target } \\
\text { consumers. } \\
\text { Location relates to } \\
\text { decisions made by } \\
\text { the company } \\
\text { regarding where } \\
\text { operations and staff } \\
\text { will be located, the } \\
\text { most important of } \\
\text { these locations is } \\
\text { the type and level of } \\
\text { interaction involved } \\
{[6]}\end{array}$ & $\begin{array}{l}\text { The location } \\
\text { of Lasiana } \\
\text { Beach is seen } \\
\text { from several } \\
\text { aspects }\end{array}$ & $\begin{array}{l}\text { 13) } \begin{array}{l}\text { Located on the main } \\
\text { highway }\end{array} \\
\text { 14) } \text { Close to other facilities } \\
\text { such as markets and } \\
\text { hotels } \\
\text { 15) Public transportation is } \\
\text { bypassed }\end{array}$ & $\begin{array}{l}5=\text { Strongly Agree } \\
4=\text { Agree } \\
3=\text { Quite Agree } \\
2=\text { Disagree } \\
1=\text { Strongly Disagree }\end{array}$ \\
\hline 5 & $\begin{array}{l}\text { Physical Proof } \\
\text { (X5) } \\
\text { Physical evidence is } \\
\text { visual or other } \\
\text { tangible clues that } \\
\text { provide evidence of } \\
\text { service quality. }\end{array}$ & $\begin{array}{l}\text { Building } \\
\text { design, } \\
\text { cleanliness } \\
\text { and regular } \\
\text { shanties in the } \\
\text { coastal area of }\end{array}$ & $\begin{array}{l}\text { 16) Design the entrance gate } \\
\text { and the Lopo in the area } \\
\text { 17) Regularity of traders' } \\
\text { places } \\
\text { 18) Trash is available } \\
\text { 19) Toilet is adequate }\end{array}$ & $\begin{aligned} 5 & =\text { Very Good } \\
4 & =\text { Good } \\
3 & =\text { Good Enough } \\
2 & =\text { Not good } \\
1 & =\text { Very Bad }\end{aligned}$ \\
\hline
\end{tabular}




\begin{tabular}{|c|c|c|c|c|c|}
\hline & $\begin{array}{l}\text { Because } \\
\text { performance of } \\
\text { intangible services } \\
\text { physical evidence } \\
\text { gives clues about } \\
\text { the quality of the } \\
\text { service and in some } \\
\text { cases will greatly } \\
\text { affect customers } \\
\text { (especially new } \\
\text { customers) in } \\
\text { assessing } \\
\text { service [10] }\end{array}$ & Lasiana & 20) & Sufficient vehicle parking & \\
\hline 6 & $\begin{array}{l}\text { People (X6) } \\
\text { People are all actors } \\
\text { who play a role in } \\
\text { the presentation of } \\
\text { services so that they } \\
\text { can influence buyer } \\
\text { perceptions. All } \\
\text { employee attitudes } \\
\text { and actions and } \\
\text { employee } \\
\text { appearances have an } \\
\text { influence } \\
\text { consumer on } \\
\text { perceptions or the } \\
\text { success of service } \\
\text { delivery [3] }\end{array}$ & $\begin{array}{l}\text { Parties that } \\
\text { are met } \\
\text { directly by } \\
\text { tourists who } \\
\text { come to visit } \\
\text { in the coastal } \\
\text { area of } \\
\text { Lasiana }\end{array}$ & $\begin{array}{l}\text { 21) } \\
\text { 22) } \\
\text { 23) } \\
\text { 24) }\end{array}$ & $\begin{array}{l}\text { Friendliness of the } \\
\text { manager } \\
\text { Adequate employee } \\
\text { availability } \\
\text { Friendliness of the traders } \\
\text { around } \\
\text { The speed of the manager } \\
\text { in dealing with tourist } \\
\text { problems }\end{array}$ & $\begin{array}{l}5=\text { Very Good } \\
4=\text { good } \\
3=\text { Good Enough } \\
2=\text { Not good } \\
1=\text { Very Bad }\end{array}$ \\
\hline 7 & $\begin{array}{l}\text { Process (X7) } \\
\text { Process is a method } \\
\text { of operation or a } \\
\text { series of certain } \\
\text { actions that } \\
\text { generally take the } \\
\text { necessary steps in a } \\
\text { predetermined } \\
\text { sequence. } \\
\text { process A } \\
\text { explaining the } \\
\text { methods and work } \\
\text { order of the } \\
\text { operating system } \\
{[10]}\end{array}$ & $\begin{array}{l}\text { Matters } \\
\text { relating to the } \\
\text { activities } \\
\text { found ranging } \\
\text { from entering } \\
\text { the area to } \\
\text { utilizing } \\
\text { services in the } \\
\text { Coastal area }\end{array}$ & $\begin{array}{l}25) \\
\text { 26) } \\
27)\end{array}$ & $\begin{array}{l}\text { Queue into the tourist } \\
\text { attraction smooth } \\
\text { Fast food served } \\
\text { Speed in using } \\
\text { available facilities }\end{array}$ & $\begin{array}{l}5=\text { Strongly Agree } \\
4=\text { Agree } \\
3=\text { Quite Agree } \\
2=\text { Disagree } \\
1=\text { Strongly Disagree }\end{array}$ \\
\hline 8 & $\begin{array}{l}\text { Tourist decision to } \\
\text { visit Lasiana beach } \\
\text { (Y) } \\
\text { Purchasing } \\
\text { decisions represent } \\
\text { a person's attitude in } \\
\text { relation to buying or } \\
\text { using a product in } \\
\text { the form of goods or }\end{array}$ & $\begin{array}{l}\text { Recognition } \\
\text { of the need for } \\
\text { recreation, } \\
\text { feelings after } \\
\text { using tourism } \\
\text { services and } \\
\text { actions taken } \\
\text { after using } \\
\text { tourism }\end{array}$ & $\begin{array}{l}\text { 28) } \\
\text { 29) }\end{array}$ & $\begin{array}{l}\text { Ease of obtaining } \\
\text { information } \\
\text { Feel satisfied to visit } \\
\text { Lasiana Beach } \\
\text { Recommend Lasiana } \\
\text { beach to family and } \\
\text { friends }\end{array}$ & $\begin{array}{l}5=\text { Strongly Agree } \\
4=\text { Agree } \\
3=\text { Quite Agree } \\
2=\text { Disagree } \\
1=\text { Strongly Disagree }\end{array}$ \\
\hline
\end{tabular}




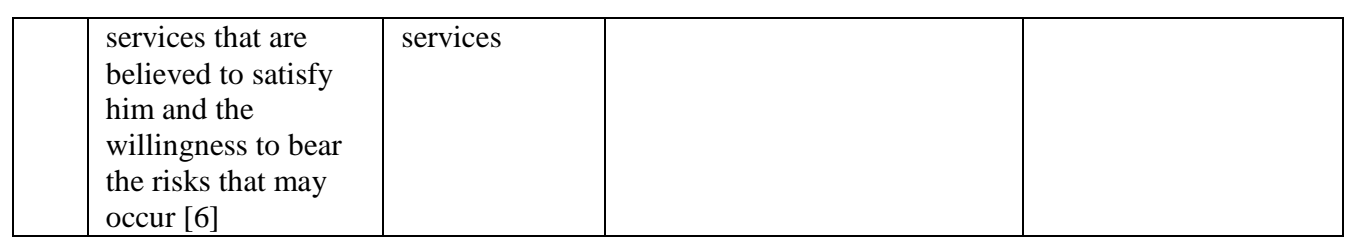

The explanation in Table 1 above is the theoretical foundation to clarify the focus of the problem under study, and also as a basis for formulating research hypothesis. In connection with this study focused on the seven independent variables with the definition proposed by experts, namely the definition of the priduct, price, promotion, location, physical evidence, people and processes while the dependent variable, namely the decision of tourists. Whereas operational definition and indicators are the actual picture of marketing mix applied by the manager of the Kupang City Lasiana Beach area which is assessed by tourists who come to visit, using the Likert model attitude scale[11].

\section{Research Method}

The method used is a mixed method with a sequential explanatory strategy which is where the researcher starts with a quantitative method by testing a theory or concept, then proceed with a qualitative method approach.

For answer the research problem and the purpose of the first and second study used the approach quantitative. Population (tourists who come to visit) less over 3000 people per month, a sample set of researchers as many as 150 tourists who will be the respondent to answer the questionnaires were distributed. Respondents are those who happened to be found in the Lasiana coast. Questionnaire concluded valid if the statement item meet the criteria of validity if $\mathrm{r}$ arithmetic $\geq 0.30$, and concluded reliable when alpha $\geq 0.60$ then point statement said reliable[12]. Validity and Reliability testing is done using the SSPS (Statistical Product and Service Solution) version 16 for window program. The research hypothesis to answer the first and second problem formulations is $\mathrm{H} 1=$ Marketing mix consisting of product $(\mathrm{x} 1)$, price $(\mathrm{x} 2)$, promotion $(\mathrm{x} 3)$, location $(\mathrm{x} 4)$, physical evidence $(\mathrm{x} 5)$, person $(\mathrm{x} 6)$ and process $(\mathrm{x} 7)$ simultaneously influence the decision to visit tourists to the beach of Lasiana (Y) while H2 $=$ Marketing mix consisting of product $(\mathrm{x} 1)$, price $(\mathrm{x} 2)$, promotion $(\mathrm{x} 3)$, location $(\mathrm{x} 4)$, physical evidence (x5), person ( $\mathrm{x} 6$ ) and process (x7) have a partial effect on the decision to visit tourists to the beach of Lasiana (Y). Criteria for a test hypothesis by looking at the results significant less than 0.05 conclusions accepting the hypothesis [13]

To answer the research problem and at the same time the third research objective used a qualitative approach. With triangulation data techniques (observation, in-depth interviews and documentation). The informant who was used as the source was the Chairperson of the Kupang City Lasiana Coastal Area, traders selling in the coastal area and Community Leaders. While the rating researchers took the finer points of processing Questionnaire (approach quantitative) beforehand. Then the researchers summarize it in the Classic SWOT matrix 


\begin{tabular}{|l|l|l}
\hline Extemal Factors & \multicolumn{1}{|c}{$\begin{array}{c}\text { Weakness } \\
\text { (W) }\end{array}$} \\
\hline $\begin{array}{l}\text { Opportunity } \\
(0)\end{array}$ & $\begin{array}{l}\text { S - O Strategy } \\
\text { Use power to take advantage of } \\
\text { Opportunities }\end{array}$ & $\begin{array}{l}\text { W-O strategy } \\
\text { Overcome Weakness by utilizing Opportunities }\end{array}$ \\
\hline $\begin{array}{l}\text { Threat } \\
(T)\end{array}$ & $\begin{array}{l}\text { S-T Strategy } \\
\text { Use power to avoid threats }\end{array}$ & $\begin{array}{l}\text { W-T strategy } \\
\text { Minimize weaknesses and avoid threats }\end{array}$ \\
\hline
\end{tabular}

Figure 1 Classic SWOT matrix

Source: (Muhamad,Suwarsono 2012:175)

\section{The Results Of Research}

To answer the first research problem will be seen based on the results of the F Test (ANOVA

Table 2. F Test Results The Effect of Marketing Mix on the Decision to Visit Lasiana Beach Travelers

\begin{tabular}{|c|c|c|c|c|c|c|}
\hline \multicolumn{2}{|l|}{ Model } & $\begin{array}{c}\text { ANOVA }{ }^{\circ} \\
\text { Sum of } \\
\text { Squares }\end{array}$ & $\mathrm{df}$ & $\begin{array}{c}\text { Mean } \\
\text { Square }\end{array}$ & $\mathrm{F}$ & Sig \\
\hline \multirow[t]{3}{*}{1} & Regression & 255,961 & 7 & 36,566 & 6,770 & $.000^{\mathrm{a}}$ \\
\hline & Residual & 550,911 & 142 & 5,401 & & \\
\hline & Total & 806,873 & 149 & & & \\
\hline & $\begin{array}{l}\text { a. Predictors: } \\
\text { X7, X4, X5, } \\
\text { X3 } \\
\text { b. Dependent } \\
\text { Variable: Y }\end{array}$ & $\begin{array}{l}\text { onstant), } \\
\text { X1, X6, }\end{array}$ & & & & \\
\hline
\end{tabular}

Source: SSPS data processing results, 2019

In Table 2 the results of data processing above shows that simultaneously (together) seven independent variables influence the decision of visiting tourists. This can be seen from the results of the significant value (in the sig column) which is equal to 0,000 . This value is smaller than the significant level of 0.05 . The conclusion is accepting H1 = Marketing mix consisting of product (x1), price (x2), promotion (x3), location (x4), physical evidence (x5), person (x6) and process (x7) simultaneously influencing the decision to visit tourists to Kupang City Lasiana Beach (Y). Means, the answer to the first problem formulation namely; there is a simultaneous influence of the product, product price, price, promotion, location, physical evidence, people and processes on the decision of tourists visiting Lasiana Beach

To answer the second research problem will be seen based on the results of the $\mathrm{T}$ Test output (Coefficients a)

In the following Table 3 result of $\mathrm{T}$ test be partially variable marketing mix affects the decision of visiting tourists. Seen in (column sig) each marketing mix variable has a smaller value $(<)$ than the significance level of 0.05 . In conclusion, accepting $\mathrm{H} 2=$ Marketing mix consisting of product (x1), price (x2), promotion (x3), location (x4), physical evidence $(\mathrm{x} 5)$, person (x6) and process (x7) partially influences the decision visiting tourists to Lasiana 
beach, Kupang. Means, the answer to the second problem formulation is that there is a partial effect (each) of the marketing mix variable which is product, product price, price, promotion, location, physical evidence, people and the process of tourists' decision to visit Kupang City's Lasiana Beach.

Table 3 T Test Results The Effect of Marketing Mix on the Decision to Visit Lasiana Beach Travelers

Coefficients a

\begin{tabular}{|l|l|c|c|c|c|c|}
\hline \multicolumn{2}{|c|}{} & \multicolumn{2}{|c|}{$\begin{array}{c}\text { Unstandardized } \\
\text { Coefficients }\end{array}$} & $\begin{array}{c}\text { Standardized } \\
\text { Coefficients } \\
\text { Beta }\end{array}$ & $\mathrm{t}$ & sig \\
\cline { 3 - 4 } \multicolumn{2}{|c|}{1} & B & Std.Eror & & \\
\hline & (Constant) & 2,948 & 3,937 & & .749 & 456 \\
& x1_prduk & .067 & .034 & .179 & 1995 & .499 \\
& x2_harga & .499 & .064 & .065 & 1.762 & .048 \\
& x3_promosi & .148 & .068 & .203 & 2.163 & .033 \\
& x4_lokasi & .988 & .153 & .058 & 2.645 & .018 \\
& x5_bukti & .039 & .961 & .034 & 2.401 & .499 \\
& x6_orang & .118 & .499 & .218 & 1.697 & .038 \\
& x7_proses & .117 & .052 & .204 & 2.234 & .028 \\
\hline
\end{tabular}

a. Dependent Variable: y1 decision

Source: results of SSPS data processing, 2019

When seen from the test $\mathrm{R}^{2}$ ( determination coefficient test) in Table 4 below, it can be seen that the contribution to the independent variables of the product (x1), price $(\mathrm{x} 2)$, promotion $(\mathrm{x} 3)$, location $(\mathrm{x} 4)$, physical evidence $(\mathrm{x} 5))$, people $(\mathrm{x} 6)$ and process $(\mathrm{x} 7)$ to dependent variable is $55.3 \%$. This means that around $44.7 \%$ were not included or not taken into account in this study.

Table 4 Determination Coefficient Results

Summary Model ${ }^{\circ}$

\begin{tabular}{|c|c|c|c|}
\hline Model & R & R Square & Adjusted R Square \\
\hline 1 & .744 a & .553 & .428 \\
\hline
\end{tabular}

a. Predictors: (Constant), x7_process, x3_promosi, x5_bukti, x6_orang, x4_location, x1_product, x2_price

To answer the third research problem, it can be presented in the Classic SWOT matrix so as to produce an alternative model of marketing strategy for the Manager of the Lasiana Coast region 


\begin{tabular}{|c|c|c|}
\hline Intema1 factors & $\begin{array}{l}\text { Strenghts } \\
\text { (S) }\end{array}$ & $\begin{array}{c}\text { Weaknesses } \\
\text { (W) }\end{array}$ \\
\hline External factors & $\begin{array}{l}\text { 1. Strategic location located on the edge } \\
\text { of the main highway as the image } \\
\text { 2. Already famous as the } \\
\text { of tourist beach dor atawan } \\
\text { derived from the } \mathrm{K} \text { ota Kupang } \\
\text { 3. An attractive beach panorama at } \\
\text { sunset } \\
\text { 4. Facilities in areas such as parking } \\
\text { lots, adequate toilets } \\
\text { 5. Food and beverage vendors available }\end{array}$ & $\begin{array}{l}\text { 1. Lack of communication between } \\
\text { the manager of the coastal area } \\
\text { (provincial government) and } \\
\text { traders in the coastal area about } \\
\text { determining the tariff for the use of } \\
\text { shanties } \\
\text { 2. Administration that has not been } \\
\text { managed propery } \\
\text { 3. Lack of awareness of people living } \\
\text { in coastal areas about cleanliness } \\
\text { 4. Inactive promotion }\end{array}$ \\
\hline $\begin{array}{l}\text { Opportunities } \\
\text { (O) } \\
\text { 1. The development of online media is } \\
\text { increasingly rapid } \\
\text { 2. Availability of a workforce, } \\
\text { especially in the Kupang City area } \\
\text { 3. The most visitors are the younger } \\
\text { generation } \\
\text { 4. Community awareness of the need } \\
\text { 5. Strecreation } \\
\text { terte-owned enterprises support in } \\
\text { Lasiana Coast area }\end{array}$ & $\begin{array}{c}\text { SO Strategy } \\
\text { Product Variations }\end{array}$ & $\begin{array}{c}\text { wO strategy } \\
\text { Promotion of Media Promotion }\end{array}$ \\
\hline $\begin{array}{l}\text { Threats } \\
\text { (T) } \\
\text { 1. The economic condition is less stable } \\
\text { 2. It is located far from the airport } \\
\text { 3. Many beach resorts have sprung up } \\
\text { in the Kupang City area }\end{array}$ & $\begin{array}{c}\text { ST Strategy } \\
\text { Tari ff standard setting policy }\end{array}$ & $\begin{array}{l}\text { WT strategy } \\
\text { Extra Services }\end{array}$ \\
\hline
\end{tabular}

\section{Discussion}

Because this study uses a mixed method with a sequential explanatory strategy, first, the researcher starts with a quantitative method. Limitation of the problem set is the marketing mix variable and the decision to visit tourists, as well as the definition of each variable raised by experts. Then the researchers presented the Research Hypothesis, namely H1 and H2. Respondents (tourists) were sampled as many as 150 people who happened to be found in the Lasiana Coast area to fill out a questionnaire designed by researchers. The results of data processing show that simultaneous and partial marketing mix has an effect on the decision of visiting tourists (seen in Table 2 and Table 3 in the sig column), meaning receiving $\mathrm{H} 1$ and $\mathrm{H} 2$. Location variable becomes the dominant variable that influences their visiting decision with a significant value (0.018). The results of data processing also show that the contribution of seven marketing mix variables is $55.3 \%$, meaning there are other things beyond the marketing mix variable that are not examined.

The qualitative approach becomes the next stage with the consideration of researchers to dig deeper information into the marketing mix aspects. Data obtained through observation, documentation, literature study and in-depth interviews with parties who were made informants namely the Chairperson of the Management of the Lasiana Coastal Area, also the traders who sell in the Lasiana coastal area, and community leaders around the Lasiana Coastal area. After the data has been reduced, the results are presented in the form of a Classic SWOT matrix, which illustrates the strengths and weaknesses that come from the management of the Lasiana Coast area in this case the Provincial Government of East Nusa Tenggara. What comes from inside the environment are various things that can be easily controlled. While opportunities and threats are various things that are difficult to control and require adjustments so they can exist. Seeing the results of the quantitative approach shows positive results in the 
equation $\mathrm{Y}=2.948+0.067 \mathrm{X} 1+0.049 \mathrm{X} 2+0.148 \mathrm{X} 3+0.098 \mathrm{X} 4+0.039 \mathrm{X} 5+0.118 \mathrm{X} 6+$ $0.117 \mathrm{X} 7+\mathrm{e}$ (in Table 3 Unstandardized Coefficients column, column B) From the equation can explained that: If these seven independent variables are not considered or improved and monitored, the decision to visit tourists will be constant or even decline.

To produce a marketing mix model to increase the interest in visiting, it turns out that the management in this case the Provincial Government needs to play an active role in working with local traders, the community and outside parties such as hotels, airports, academics and so on.

\section{Conclusions}

1. There is a simultaneous influence of the marketing mix variable consisting of product (X1), price (X2), promotion (X3), location (X4), physical evidence (X5), person (X6) and process $(\mathrm{X} 7)$ on the decision of visiting tourists to the Lasiana beach area $(\mathrm{Y})$ with a significance of 0.035 .

2. There is a partial effect of each marketing mix variable, namely product (X1) 0.049, price (X2) 0.048, promotion (X3) 0.033, location (X4) 0.018, Physical Evidence (X5) 0.049 , people (X6) 0.38 , process (X7) 0,028 . It can also be concluded that Location is the most dominant variable. And The contribution of seven marketing mix variables was $55.3 \%$

3. Strategi SO is the Product Variations Travel Made like leasing a float, or a speed boat for tourists, make a swimming pool, renting ship fish around the pier.

The WO strategy is Strengthening Promotions by utilizing media such as local radios or local newspapers. Distributing brochures to hotels located close to Lasiana Beach.

The ST Strategy is the NTT Provincial Government's Tariff Standards having the power to make uniform entrance tariffs for coastal zones close to each other. The stalls tariff needs to be reviewed.

WT Strategy Extra services to visiting tourists. Providing free dining bonus vouchers to tourists who frequently visit the Lasiana beach area, attach photos or signatures of famous people who have visited Lasiana beach area

\section{Reference}

[1] Pitana, I. Gde. Dirata, I Ketut. Pengantar Ilmu Pariwisata. Andi. Yogyakarta, page 86 and 152. (2016)

[2] Assauri, Sofyan : Manajemen Pemasaran. Rajawali Press. Jakarta (2008)

[3]Hurriyati, Ratih : Manajemen Pemasaran dan Loyalitas Pelanggan . Alfabeta. Bandung, page 47,62 (2010)

[4]Muhamad, Suwarsono : Manajemen Strategi Teori dan Kasus. YKPN. Yogyakarta, page 176-177 (2012)

[5]Law No.10 of 2009

[6]Kotler, Philip, Keller, Kevin Lane : Manajemen Pemasaran Volume 1 Issue 12 . Language Edition Indonesia Penerjemeh Benjamin Molan. Index. Jakarta, (2018)

[7] Suwantoro, Gamal: Dasar-dasar Pariwisata.Andi.Yogyakarta. page 48 (2004).

[8] Laksana, Fadjar: Manajemen Pemasaran Pendekatan Praktis. Graha Science. Yogyakarta. Page 105, (2008) 
[9]Gitosudarmo, Indiriyo: Introduction to Business . BPFE. Yogyakarta. page, 237, (2008)

[10] Lovelock and Wright: Manajemen Pemasaran Jasa . Index. Jakarta, page 18, 20, (2005)

[11] Riduwan : Metode dan Teknik Menyusun Tesis. Alfabeta Atriyo. Bandung, (2008).

[12] Sugiyono:Metode Penelitian. Alfabeta Bandung.(2018)

[13] Supranto : Statistic Theory, Applications. VI Edition. Volume 2. Erlangga. Jakarta.(2009) 